Disponível em:

http://editora.unoesc.edu.br/index.php/race

Race, Joaçaba, v. 15, n. 2, p. 419-446, maio/ago. 2016

\title{
SUSTAINABLE PUBLIC BIDDINGS: THE CASE OF UNIVERSIDADE FEDERAL DA FRONTEIRA SUL'S UNIVERSITY RESTAURANT
}

Licitações públicas sustentáveis: o caso do Restaurante Universitário da Universidade

Federal da Fronteira Sul

Josiane Weber

E-mail: josiweber@yahoo.com.br

Post-graduate in City Management Control from Universidade do Oeste de Santa

Catarina;

Masters in Professional Business student from Universidade do Oeste de Santa Catarina; Administrator at Universidade da Fronteira Sul.

Nelson Santos Machado

E-mail: nelson.machado@unoesc.edu.br

Doctor in Production Engineering from Universidade Federal de Santa Catarina;

Master in Business from Universidade Federal de Santa Catarina; Professor and

Researcher of Universidade Federal de Santa Catarina Chapecó.

Contact address: Avenida Nereu Ramos 3777 D, Seminário, 89813-000, Chapecó,

SC, Brasil.

Article received on April 4 $4^{\text {th }}$ 2016. Accepted on April 17 2016. 
Abstract

This study attempted to verify how the Universidade Federal da Fronteira Sul (UFFS) contemplated the three pillars of sustainability on the bidding processes to the implantation of its university restaurants. A qualitative research through a case study was performed. The methods of data collection were literature, documentary research to analyze 11 cases occurred between 2010 and 2014, and interviews, in order to identify the responsible for the area's perception concerning the sustainable procurements. Data analysis revealed that, in general, the involved people have a wide perception on the subject, covering the three pillars of sustainability. The Institution seeks to include sustainability criteria in their bidding processes, however, it is observed noticeable emphasis on economic and environmental criteria, confirming what has been shown in theory and studies related. Considering these aspects, it is concluded that, in order to meet the three pillars of sustainability, the institution must also pay attention to the social issues, even though to do so it needs to include additional criteria to the ones proposed by legislation. Among the proposals of improvements, two of them stand out: investing in academic community's awareness and creating a Sustainability Center of institutional nature to reflect and plan the advances, in particular, in Social Pillar.

Keywords: Sustainability. Sustainable public biddings. Triple Bottom Line.

\section{Resumo}

No presente estudo buscou-se verificar como a Universidade Federal da Fronteira Sul (UFFS) contemplou os três pilares da sustentabilidade nos processos de licitação para implantação de seus restaurantes universitários. Foi realizada uma pesquisa qualitativa, por meio de um estudo de caso. Os métodos de coleta de dados foram pesquisa bibliográfica, pesquisa documental para analisar onze processos ocorridos entre 2010 e 2014 e entrevistas, visando identificar a percepção dos responsáveis pela área no que diz respeito às compras sustentáveis. A análise dos dados revelou que, no geral, os envolvidos têm uma percepção ampla sobre o assunto, contemplando os três pilares da sustentabilidade. A instituição procura incluir critérios de sustentabilidade nos processos licitatórios, no entanto, observa-se notada ênfase nos critérios econômicos e ambientais, confirmando o que vem sendo apresentado na teoria e estudos relacionados. Considerando-se esses aspectos, conclui-se que para o atendimento aos três pilares da sustentabilidade, a Instituição precisa atentar-se também à questão social, mesmo que para isso precise incluir critérios adicionais aos propostos pela legislação. Entre as propostas de melhorias destaca-se investir na conscientização da comunidade acadêmica e na criação de Núcleo de Sustentabilidade de caráter institucional para refletir e planejar os avanços, em especial no Pilar Social.

Palavras-chave: Sustentabilidade. Licitações públicas sustentáveis. Triple Bottom Line. 


\section{INTRODUCTION}

The 1988 Federal Constitution, in its article 22, institutes that the rules for bidding need to be followed by the direct, autarchic and foundational public administration of the Union, States, Federal District and Municipalities, as well as by the public companies and mixed-economy societies. Aiming to regulate the bidding process within the Public Administration, in 1993 the Law of Biddings and Contracts is created.

The hires and acquisitions in public administration must happen in order to ensure transparency on public management. In this context, the bidding process may be seen as the main means of control in the public resources application.

Considering the concern about sustainability and about the sustainable development, based on its procurement potential and, still, on its responsibility in accomplishing a sustainable management, the Brazilian government has been expanding the scope on the public hires area, evaluating not only the most advantageous proposals to the administration. It starts to address sustainability criteria to be followed by the service provider companies and the product provider ones.

The regulation of these changes in public biddings takes place from the Normative Instruction n. 01/2010 enacted by the Ministry of Planning, Budget and Management (MPBM). On June $5^{\text {th }}$, 2012, the Federal Government enacts the Federal Decree n. 7.746, stablishing criteria to promote the national sustainable development in the hires held by Federal Public Administration.

As the other bodies of Federal Public Administration, the Public Higher Education Institutions need to meet the criteria stablished in legislation, as well as promote Sustainability, in its economic, social and environmental aspects.

The Universidade Federal da Fronteira Sul (UFFS) was created by the Law $n$. 12.029, September $15^{\text {th }}, 2009$. Since then, it has been developing numerous activities, like: construction of buildings for permanent premises, lease of space for provisional operation, hiring of servants to compose the administrative and teaching technical staff, acquisition of furniture, equipment, permanent material and consumable ones, hiring of outsourced security and cleaning services, drivers and specialized architectural and engineering services. So, a huge range of acquisitions and hiring were happening simultaneously. University restaurants from Universidade Federal da Fronteira Sul, as several other sectors of the institution, are in process of implantation.

In this sense, the problem that guided the development of this study consists in answering the following question: Do the executed hiring to the implantation of the University Restaurant of UFFS meet the three pillars of sustainability? 
The development of this study is justified by demonstrating how the legislation provides this sustainable bidding process and how it effectively occurs in practice by means of a case study in Universidade Federal da Fronteira Sul. Through sustainable management, following the sustainable tripod premises, the Institution will be able to optimize the distribution and utilization of public resources, disseminate and promote aspects related to sustainability, and, also, improve its image to the society.

UFFS had strong participation of social movements to its creation, with characteristics like the social control very active. This fact justifies the elaboration of a study that presents data of sustainable bidding processes that take place in the Institution. Besides the general society, it is extremely important that the servants are aware of how the sustainable bidding process happens. This way, they will be able to be more efficient and more effective when developing their functions.

Thus, as general objective of this study, it was sought to verify if the executed hiring to the implantation of the University Restaurant (UR) of UFFS meet the three pillars of sustainability. As specific aims, there are: to identify the legislation that regulates the bidding process; to compare the legal requirements present in the legislation to the premises preconized by Elkington (2001); to analyze the bidding processes executed to the implantation of the University Restaurant of UFFS; to identify the perception of those responsible for the area in this Institution about the sustainable procurement; and to propose adjustments and improvements to the bidding process of sustainable nature.

In summary, the accomplishment of this study, besides working as a guide to the sustainable bidding process in Universidade Federal da Fronteira Sul as it seeks to demonstrate which criteria are stablished by legislation and which ones are being applied, will also help the citizens in the function of social control, because it will allow a wider view of the procurements and biddings in the implantation of the University Restaurant of the referred Institution.

The organization of this study is composed by five sections in addition to this introduction: section 2 presents the theoretical background related to sustainability and to the legislations that regulate the bidding process and the sustainable hiring and procurement; section 3 presents the case and the methodology applied; section 4 is constituted by the data presentation and analysis; and section 5 presents the final considerations. 


\section{SUSTAINABILITY}

Sustainability and sustainable development are topics that, despite being currently in vogue, have been discussed from the 70s. Since then, events and organizations related to the development of sustainability act sensitizing the citizens and public managers to this discussion, involving several sectors of the society (MELO, 2013).

The term Sustainability got to be used specially after the publication of Brundtland Report (VAN BELLEN, 2004). The report, originally called “Our Common Future”, was the result of the World Commission on Environment and Development's work (WCED). According to this Commission (1991, p. 9, our translation), the sustainable development is "[...] the one that meets the needs of the present without compromising the future generations' ability to meet their own needs.”

The development until recently was seen only on the economic perspective. According to this initial concept, the economic growth meant development, and now it needs to completely incorporate the concept of sustainability, regarding the three dimensions composing it: economic, social and environmental (WORLD COMMISSION ON ENVIRONMENT AND DEVELOPMENT, 1991). According to Sen (2010), development means the removal of restrictions, because they let people with few choices and opportunities, focusing the "development as freedom”. On this perspective, development would be decreasing the non-freedoms like poverty, tyranny, few economic opportunities, social systems of deprivation, neglect in the provision of public goods, intolerance and authoritarianism of oppressive regimes.

If the development had its concept linked to economic issues, sustainability in turn was associated to environmental issues. According to Elkington (2001), sustainability is not linked only to issues of environment preservation. This is only one of its dimensions. It is a complete system involving the economic, social and environmental aspects.

The importance of the economic and environmental issues before the reality we live is undeniable. The population growth and, consequently, the industrial and commercial production one put at risk the preservation of the natural resources available in this Planet. The situation is really critic, however, it is important not to leave the social issue on the sidelines of the discussion. According to Sachs, Lopes and Dowbor (2010), the main challenges are: saving the Planet, reducing the inequality, assuring the access to decent work and correcting the productive priorities. The crisis has taken gigantic proportions, reaching an increasing number of individuals around the world, however, this fact may be seen as a changing opportunity. 
Sustainable development means to perfect the concept of development, aligning the economic and social progress to the preservation of the ecosystems; it fundamental characteristics are economic growth, social equity and ecological balance (BINSWANGER, 2002; MELO, 2013). The economic sustainability, according to Araújo et al. (2006), includes aspects related to market, quality, cost and competitiveness, among others. In the environmental sustainability, clean technologies, recycling, environmental impacts, environmentally friendly product, and others are contemplated. The social sustainability is focused on the social responsibility, on the support to the community growth, and to the promotion and participation in social projects.

The Triple Bottom Line (TBL) method, according to Oliveira et al. (2012), is known as 3P (People, Planet and Profit). When analyzing each item, it is observed the economic one, with the goal of creating viable enterprises, the environmental one, which aims the reduction of damage to the environment, and the social one, which aims fair actions to the stakeholders.

Created by the economist John Elkington, the Triple Bottom Line (TBL) model considers three aspects referring to sustainability: the environmental, the economic and the social. The aim of the method is to seek a balance between the economic efficiency, the social equity and the environmental preservation. According to Elkington (2001), the intersection between the social and the environmental pillars results in environmental justice. The intersection between the economic and the environmental aspects create eco-efficiency. However, there are still many challenges like the environmental accountability and the ecological tax reform. The intersection between the economic and the social pillars generates entrepreneurial ethics. Each one of the pillars individually has a great importance to sustainability, as well as the items resulting of the intersection of these pillars.

When presenting definitions related to economic pillar of sustainability, Elkington (2001) reports that the economic theory presents the economic capital subdivided in: physical capital, financial capital, human capital and intellectual capital. The author emphasizes that in the tradition view the economic pillar would be summarized to the company's profit, based only in numeric data. The accountability reports may present the profits and losses, the balance, and, still, the total losses and profits acknowledged. A wide view of this pillar requires thinking economic sustainability in the long run. There are still few indicators of economic sustainability, but items as sustainability of services and products demand and in relation to the prices must be included to the profit and innovation margin. 
When it is about the environmental pillar, the focus in related to the preservation of the Planet and it is represented by the environment. When discussing about the environmental pillar, Elkington (2001) highlights the difficulty of measuring the natural capital of a company, he cites the example of a forest, the fact that cutting a tree does not enable to measure the natural capital. There are several other aspects as the constitution of the forest ecosystem, the generated benefits, the fauna and the flora and still, the products that can be traded. The natural capital may be divided in critical natural capital, fundamental "[...] to the maintenance of life and of the ecosystem's integrity” and the natural capital renewable or replaceable (ELKINGTON, 2001, p. 73, our translation). The actions to renewal, substitution and recuperation of the natural capital involve, for example, relocation of sensitive ecosystems, environmental alternatives, recovery of deserts and use of substitutes to the limited fossil fuels, as solar panels.

The social pillar is associated to the population's life quality, to the human rights and to the work conditions. According to Elkington (2001), the social capital considers the human capital, considering aspects as education, health and abilities, but he highlights it must cover wider aspects in relation to the wealth generation and to the society's health. It is concluded that the sustainable development should be fostered searching an integration of economic, social and environmental aspects of sustainability. To accomplish these aims, it is necessary to review the consumption habits. Hereinafter, some aspects related to procurement and public hires are highlighted.

\subsection{SUSTAINABLE BIDDINGS AND LEGAL REQUIREMENTS}

In order to regulate the bidding process in the Public Administration scope, on June $21^{\text {st }}$, 1993, the Law of Biddings and Contracts n. 8.666/93 was approved, according to which, all entities of direct, indirect and foundational Public Administration are obliged to hire through bidding process, offering equality of conditions to all the bidders. It provides the principles to be observed to the realization of a bidding process: legality, impersonality, morality, publicity, efficiency, administrative probity, equality (isonomy), objective judgment, fairness, economy and the principle of adherence to the bid announcement. Its aim is to promote treatment equality, ethical conduct by the administrator, dissemination of its activities and to achieve positive results for the public service.

The judgement criteria to the choice of the best proposal is the kind of bidding, which can be lower price, better technic or technic and price. In the case of 
concessions and permissions of public services, as judgment criterion it may be considered the lowest value, the best offer or the combination of both (CASTRO; LIMA, 2011).

The means used by the Public Administration to the acquisition of goods or hires of service, according to Law n. 8.666/93, are modalities of bidding: call, competition, making prices, auction and competition (BRASIL, 1993).

The Auction may be live or electronic, and it is destined to the selection of the most advantageous proposal of hires of goods or common service. It is composed by an initial competitive phase, in which the bidders make successive proposals, and in the subsequent phase it is done the verification of qualification and satisfactoriness requirements of the offers (JUSTEN FILHO, 2009). One of the advantages of this modality is on the debureaucratization of the bidding process, having in mind that in this modality an inversion of phases takes place.

The cases in which the bidding exemption may occur are provided for in art. 24 of the Bidding Law, the unenforceability is provided for in the art. 25 and it occurs when there is no competition possibility.

Bidding is a preliminary procedure, constituted by law and promoted by the governmental bodies, aiming the promotion of competition among stakeholders that meet the requirements necessary to the good compliance of obligations which they are willing to take with the administration. A bidding process should guarantee the legality of the acquisitions and hires accomplished by the public power. According to Castro and Lima (2011), it is a previous administrative procedure which enables the contracts of the public administration. It aims to reach the most advantageous way to acquire products or to provision of service. The goal of bidding, according to Castro (2009), is to search the best hiring conditions.

The criteria that defined the best hires are, mainly, the financial ones. Considering Sustainability and the Sustainable Development, the government understands that it needs to act differently than usual in its hiring. From this perception, rules that complement the legislation on bidding are instituted, aiming to meet sustainability criteria, “[...] covering factors as quality, efficiency, environmental protection, guarantee of human rights and respect to labor laws, among others.” (ALENCASTRO; SILVA; LOPES, 2014, p. 215, our translation).

The regulation of these changes in public biddings happens from the Normative Instruction n. 01/2010 promulgated by the Ministério do Planejamento, Orçamento e Gestão (MPOG) [Ministry of Planning, Budget and Management], which stablishes environmental sustainability in the acquisition of goods, services and cons- 
tructions by the Federal Public Administration. On June $5^{\text {th }}$, 2012, the Federal Government promulgated the Federal Decree n. 7.746, stablishing criteria to promote the national sustainable development in hires held by the Federal Public Administration. The Normative Instruction n. 10/2012 of the Department of Logistics of Information Technology stablishes rules to the preparation of the Sustainable Logistics Plan, which presents necessary actions so that the institutions to comply the current legislation. On UFFS's scope, this plan started to be developed in December 2012 (BRASIL, 2010b, 2012a, 2012b).

Law n. 12.349/2010 includes the promotion of the national sustainable development as bidding goal. The norming defines several items as non-restrictive to the competitiveness, included in the art. $3^{\circ}$ of Law n. 8.666/1993, aiming the protection and promotion of the production of local goods (BRASIL, 2010d).

Agenda 21 was created in Conference Rio 92 and it is composed by actions directed to the sustainable development, including proposals to changes in the consumption patterns (BIDERMAN; MACEDO; MAZON, 2008). Another extremely important initiative is the Agenda Ambiental da Administração Pública (A3P) [Environment Agenda of Public Administration], which is another proposal of the Federal Government, through the Ministry of the Environment, to promote the good practices and sustainability in the bodies which integrate it. The program aims to: stimulate the reflection and attitude changing of the public servants about the socioenvironmental issues, including the rational use of natural resources and, yet, contribute to improve the quality of life. A3P is divided into five themes: irrational use of the natural resources and public goods, adequate management of the waste generated, quality of life in the work environment, awareness and qualification and sustainable bidding (BRASIL, 2009a).

There are, still, other legislations that deal with issues related to sustainability, as Law n. 10.257/2001, which regulates the arts. 182 and 183 of the 1988 Federal Constitution, stablishing general guidelines on the urban policy, named Statute of Cities (BRASIL, 2001), which institutes the Política Nacional sobre Mudança Climáticas (PNMC) [National Policy on Climate Change], by means of which Brazil takes voluntary commitment to the reduction of $\mathrm{CO}^{2}$ emission BRASIL, 2009b). Law n. 12.305/2010, which institutes the Política Nacional de Resíduos Sólidos (PNRS) [National Policy of Solid Waste], regulated by Decree n. 7.404/2010, which created the Comitê Interministerial da Política Nacional e Resíduos Sólidos [Steering Committee for Reverse Logistics Implantation and the Interministerial Committee of the National Policy and Solid Waste] (BRASIL, 2010a, 2010c). 
The process by which the bodies of the public administration seek to insert socioenvironmental sustainability criteria in good acquisition and service hires can be named Sustainable Public Procurement (SPP) (ALENCASTRO; SILVA; LOPES, 2014). According to the Guide of Sustainable Procurement of Fundação Getúlio Vargas, sustainable bidding aims the integration of environmental and social aspects in every phase of the government's procurement and hiring, with the aim of reducing the impacts to human health, to the environment and to the human rights (BIDERMAN; MACEDO, MAZON, 2008). It is noticed the government's concern in regulating the sustainable procurement, through the creation of Laws, Decrees and Normative Instructions, is understood that all this existing legislation and initiatives created aim at the national sustainable development.

Facing this evolution in the bidding processes, it is concluded that the legislation contemplates many aspects about sustainability. However, the monitoring of these actions with the bodies that execute them is necessary to verify the applicability of these innovations proposed by legal rules, and it is also important to find ways to implement them.

\section{METHODOLOGY}

This study was performed by Universidade Federal da Fronteira Sul (UFFS), in the period of February 2014 to June 2014. The bidding processes performed to the implantation of the University Restaurant of UFFS were analyzes, summing up 11 processes occurred between 2010 and 2014.

The research approach was qualitative, which, according to Creswell (2010), consists in understanding the meaning that the individuals attach to a social or human problem. As Godoy (1995) states, the phenomena are better understood in the context in which they occur and must be analyzed according to an integrated perspective.

The case study was its focus, approaching the biddings conducted to the implantation of the UR of UFFS. According to Creswell (2010), the case study is a method in which the researcher deeply examines an event, process, individual or group of individuals. According to Yin (2010), it is the accomplishment of an empirical investigation following a set of procedures. The study is classified as descriptive, because it has the aim of describing a phenomenon and, according to Collis and Hussey (2005), is used to identify, evaluate and describe a problem.

The data collection was held through documental research; among the advantages of the documents use as research source are the fact that they are stable, able 
to be revisited several times, exact and have broad coverage (YIN, 2010). Interviews were held with servants of the Procurement Superintendence, Department of sustainable importations and procurement and Nutrition Board. According to Bell (2008, p. 136, our translation), "[...] one of the main advantages of the interview is its adaptability." Yet, according to the author, the interview allows responses to be developed and clarified. The selection of the respondents was due to their cooperation to the development of the study for being directly connected to the issue in question. The method used to the analysis of the interviews was the content analysis. In this kind of analysis, "[...] the researcher seeks to understand the characteristics, structures and/or methods behind the messages.” (GODOY, 1995, p. 23, our translation).

The documental research, in the first place, sought to identify and organize the current legislation on the sustainable biddings, listing the laws, decrees and normative instructions and their purposes. The data were collected in reliable websites, mainly from the Federal Government. Subsequently, the processes held to the implantation of the University Restaurant were analyzed. The documents were available on the Institution's website; in some cases, it was necessary to access paper documents to complement the information available in digital format. This initial phase of the documental research is defined by Godoy (1995) as pre-analysis, which included the selection, organization and a "floating" reading of the material.

The second phase is about the exploitation of the documents, it comprises a deep reading of the material and the procedures of coding, classifying and categorizing the material (GODOY, 1995). The categories of analysis were defined by the concept of Triple Bottom Line (TBL), using the three pillars of sustainability: economic, environmental and social. To the codification of the interviews the phrase was taken as registration drive. Bardin (2011) defines registration drive as a unit to be encoded, which can be a word, a phrase or a theme. Boards were elaborated identifying the legislations and their purposes, comparatives between the analysis categories and the content of the laws, and still highlighting sustainability criteria located in every one of the processes held to the implantation of UR.

In order to assure the validity of the research in the data analysis, it was developed a triangulation which it constituted in a "[...] rationale to use several evidence sources.” (YIN, 2010, our translation). The triangulation is known, according to Bel (2008), as a multimethodological approach, for using more than one method of data collection. 
Board 1 - Summary of the methodological procedures adopted in the research

\begin{tabular}{|c|c|c|c|c|}
\hline Aims of the research & $\begin{array}{l}\text { Source of data } \\
\text { collection }\end{array}$ & Topics covered & Systematization of data & $\begin{array}{l}\text { Essential } \\
\text { authors }\end{array}$ \\
\hline $\begin{array}{l}\text { To identify the legis- } \\
\text { lations which regulate } \\
\text { the bidding process. }\end{array}$ & Bibliographic & $\begin{array}{l}\text { Laws, decrees and } \\
\text { normative instruc- } \\
\text { tions. }\end{array}$ & $\begin{array}{l}\text { - Formulation of a } \\
\text { board with the main } \\
\text { laws and their purposes; } \\
\text { - Analysis and dis- } \\
\text { cussion of the results } \\
\text { found. }\end{array}$ & $\begin{array}{l}\text { Justen Filho } \\
\text { (2009) } \\
\text { Bederman, } \\
\text { Macedo } \\
\text { and Mazon } \\
\text { (2008) } \\
\text { Legislation } \\
\end{array}$ \\
\hline $\begin{array}{l}\text { To compare the legal } \\
\text { requirements (con- } \\
\text { tents of the legisla- } \\
\text { tion x assumptions } \\
\text { recommended by } \\
\text { Elkington). }\end{array}$ & Bibliographic & $\begin{array}{l}\text { - Economic, social } \\
\text { and environmental } \\
\text { pillars of sustain- } \\
\text { ability; } \\
\text { - Sustainability crite- } \\
\text { ria in the legislation. } \\
\text { Pilares econômico, } \\
\text { social e ambiental da } \\
\text { Sustentabilidade; } \\
\text { - Critérios de susten- } \\
\text { tabilidade presentes } \\
\text { na legislação. }\end{array}$ & $\begin{array}{l}\text { - Formulation of a } \\
\text { board listing the pillars } \\
\text { with the criteria identi- } \\
\text { fied in the legislation; } \\
\text { - Analysis and dis- } \\
\text { cussion of the results } \\
\text { found. }\end{array}$ & $\begin{array}{l}\text { Elkington } \\
\text { (2001) } \\
\text { Legislation }\end{array}$ \\
\hline $\begin{array}{l}\text { To analyze the bid- } \\
\text { ding processes held } \\
\text { to the implantation } \\
\text { of the University } \\
\text { Restaurant (UFFS). }\end{array}$ & Documental & $\begin{array}{l}\text { - Economic, social } \\
\text { and environmental } \\
\text { sustainability criteria } \\
\text { in the bidding pro- } \\
\text { cesses. }\end{array}$ & $\begin{array}{l}\text { - Formulation of } \\
\text { a board listing the } \\
\text { processes and criteria } \\
\text { identified. } \\
\text { - Analysis and dis- } \\
\text { cussion of the results } \\
\text { found. }\end{array}$ & $\begin{array}{l}\text { Elkington } \\
\text { (2001) }\end{array}$ \\
\hline $\begin{array}{l}\text { To identify the } \\
\text { perception of those } \\
\text { responsible for the } \\
\text { area in the Institution } \\
\text { related to the sustain- } \\
\text { able procurement. }\end{array}$ & Interviews & $\begin{array}{l}\text { - Legislations that } \\
\text { regulate the bidding } \\
\text { process; } \\
\text { - Legal requirements } \\
\text { and sustainability } \\
\text { premises; } \\
\text { - Comprehension on } \\
\text { the concept of sus- } \\
\text { tainable procurement. }\end{array}$ & $\begin{array}{l}\text { - Formulation of a } \\
\text { board with aspects } \\
\text { related to the respon- } \\
\text { dents' perception; } \\
\text { - Analysis and dis- } \\
\text { cussion of the results } \\
\text { found. }\end{array}$ & $\begin{array}{l}\text { Elkington } \\
\text { (2001) }\end{array}$ \\
\hline $\begin{array}{l}\text { To propose adequa- } \\
\text { cies and improve- } \\
\text { ments to the bidding } \\
\text { process of sustainable } \\
\text { nature. }\end{array}$ & $\begin{array}{l}\text { Bibliographic } \\
\text { and Interviews }\end{array}$ & $\begin{array}{l}\text { Proposing improve- } \\
\text { ments. }\end{array}$ & $\begin{array}{l}\text { - Text listing the possi- } \\
\text { ble actions to improve } \\
\text { the process; } \\
\text { - Analysis and dis- } \\
\text { cussion of the results } \\
\text { found. }\end{array}$ & $\begin{array}{l}\text { Alencastro, } \\
\text { Silva and } \\
\text { Lopes (2014) }\end{array}$ \\
\hline
\end{tabular}

Source: the authors. 
Board 1 presents a summary of the methodological procedures held in the research. The next section brings the data presentation as well as their analysis and discussion.

\section{DATA PRESENTATION, ANALYSIS AND DISCUSSION}

This section presents a brief characterization of the Institution and, after, the data analysis and discussion, composed by five subsections: 4.1 presents the legislations that regulate the bidding process; 4.2 compares the legal requirements to the premises recommended by Elkington (2001); 4.3 relates the processes held to the implantation of the University Restaurant of UFFS; 4.4 presents the results of the interviews related to the perception of those responsible for the area in the Institution in relation to the sustainable procurement. The subsection 4.5 is about the proposition of adjustments and improvements to the sustainable bidding process.

Universidade Federal da Fronteira Sul (UFFS) was created by the Law n. 12. 029, on September $15^{\text {th }}, 2009$. However, the efforts to its implantation started still in 2005, with the birth of the three States of Southern region of the Pro-Federal University Movement, formed by NGOs, churches and social movements.

It has a multicampus structure, which attends the three states of the country's Southern region. Headquartered in Chapecó, Santa Catarina, it has two campuses in Realeza and Laranjeiras do Sul, in Paraná, and three in Rio Grande do Sul, in the cities of Cerro Largo, Erechim and Passo Fundo. Its six campuses are on the population of the 396 municipalities of the Mesoregion of the Southern Board.

The mission of Universidade Federal da Fronteira Sul consists of: assuring the access to education as a decisive factor to the development of the Southern board region, the professional qualification and the social inclusion; developing teaching, research and extension activities, seeking the interaction and the integration of the cities and states that compose the great border of Mercosul and its surroundings; and promoting the integrated regional development - essential condition to the guarantee of permanence of the citizens graduated in the South border region and the littoralisation reversal process now in progress.

The UFFS's profile aims to attend the needs of the mesoregion; it is intended to be a public, popular and quality university, committed to the formation of concerned citizens and to the sustainable and solidary development of the Country's Southern region. It is sought to be a democratic, autonomous university, that respects 
the plurality of thought and cultural diversity, with the guarantee of spaces to the participation of the several social subjects, establishing combat devices to social and regional inequalities, including conditions of access and permanence in higher education, specially of the population excluded of the countryside and the city. A university that has in family agriculture a structuring and dynamic sector of the development process, and which is premised on the appreciation and overcoming of the existing productive matrix (UNIVERSIDADE FEDERAL DA FRONTEIRA SUL, 2015).

The academic community is composed by about 8,000 people, among which 625 are administrative staff, 590 are teachers, and 6,788 are students. Only the positions held and the active enrollment were considered.

Board 2 - Characterization of the respondents

\begin{tabular}{|l|l|l|l|}
\hline Respondent & Formation & Position/function & Time in UFFS \\
\hline E1 & Nutrition & Nutricionist/Nutrition director & 4 years \\
\hline E2 & Biology & $\begin{array}{l}\text { Laboratory technician/ Head of the Department of } \\
\text { Import and Sustainable Procurement }\end{array}$ & 2 years \\
\hline E4 & Administration & $\begin{array}{l}\text { Administrator/Head of the Department of Bidding } \\
\text { (Crier) }\end{array}$ & 4 years \\
\hline
\end{tabular}

Source: the authors.

Board 2 presents the characterization of the respondents. The sample was selected due to the attributions of each servant. It is noticed that all the respondents perform key activities in the bidding processes held to the implantation of the University Restaurant.

\subsection{LEGISLATIONS THAT REGULATE THE BIDDING PROCESS}

Board 3 shows a summary of the main laws, decrees and normative instructions that rule the bidding process in public institutions, describing their purposes and objectives. 
Board 3 - Legislations that regulate the bidding process

\begin{tabular}{|c|c|}
\hline Laws & Purposes of the law \\
\hline $\begin{array}{l}\text { Law n. } 12.305 / 2010 \text {, reg- } \\
\text { ulated by the Decree n. } \\
7.404 / 2010 \text {. }\end{array}$ & $\begin{array}{l}\text { Solid Waste National Policy: it stablishes priority to the acquisition of } \\
\text { recycled and recycling products and that consider criteria compatible to } \\
\text { sustainable consumption patterns. }\end{array}$ \\
\hline $\begin{array}{l}\text { Decree } n .7 .746 / 2012 \text {. It } \\
\text { regulates the art. } 3^{\circ} \text { of the } \\
\text { Law n. } 8.666 / 1993\end{array}$ & $\begin{array}{l}\text { It defines parameters to sustainable procurements in public administra- } \\
\text { tion. It stablishes criteria, practices and guidelines to the promotion of the } \\
\text { national sustainable development and it institutes the Comissão Intermin- } \\
\text { isterial de Sustentabilidade na Administração Pública (CISAP) [Intermin- } \\
\text { isterial Commission on Sustainability in Public Administration]. }\end{array}$ \\
\hline $\begin{array}{l}\text { Normative instruction } n . \\
1 / 2010\end{array}$ & $\begin{array}{l}\text { It stablishes the inclusion of environmental sustainability criteria in the } \\
\text { acquisition of goods and hires of services and works without losses to the } \\
\text { competitiveness of the process. }\end{array}$ \\
\hline $\begin{array}{l}\text { Normative instruction } n . \\
10 / 2012\end{array}$ & $\begin{array}{l}\text { It stablishes the rules to the elaboration of the Plans of Sustainable } \\
\text { Logistics and Management, contained in the art. } 16 \text { of the Decree n. } \\
7.747 / 2012 \text {. }\end{array}$ \\
\hline $\begin{array}{l}\text { Law n. 8.666/1993 amend- } \\
\text { ed by Law n. } 12.349 / 2010\end{array}$ & $\begin{array}{l}\text { The alteration of the art. } 3^{\circ} \text { of the Law n. } 8.666 / 93 \text { includes as aim of the } \\
\text { bidding the promotion of the national sustainable development. }\end{array}$ \\
\hline Decree n. 5.450/2005 & It regulates the electronic auction. \\
\hline $\begin{array}{l}\text { Complementary Law n. } \\
123 / 2006\end{array}$ & $\begin{array}{l}\text { National Statute of Micro and Small Businesses, it stablishes rules of } \\
\text { differential treatment to micro and small businesses. }\end{array}$ \\
\hline Decree n. 6.204/2007 & $\begin{array}{l}\text { It regulates the differential treatment to micro and small businesses in the } \\
\text { contract with the federal public administration. }\end{array}$ \\
\hline
\end{tabular}

Source: the authors.

The legislation about the sustainable biddings is very wide. It is noticed that in the Federal Constitution there is the provision that everyone has the right to the ecologically balanced environment; it also contains the economic order (art. 225). In its art. 170, item VI, it provides the “[...] environmental protection, including by differential treatment according to the environmental impact of products and services and their development processes and delivery.” (BRASIL, 1988, our translation). The specific regulation to the sustainable biddings is really recent; from 2010 the creation of laws, decrees and instructions was intensified, aiming to normatize the governmental procurement, considering sustainability issues, emphasizing the environmental ones. It is noticed that these initiatives from the government are together with the worldwide discussions, related to the preservation of the Planet, to the consumption issues and to the sustainable development. 


\subsection{COMPARISON OF THE LEGAL REQUIREMENTS X PREMISES RECOMMENDED BY JOHN ELKINGTON}

In Board 4 there is a comparison between the three pillars of sustainability proposed by Elkington (2001) and the criteria found in legal rules.

Board 4 - Comparison pillars of sustainability versus legal requirements

\begin{tabular}{|c|c|}
\hline $\begin{array}{l}\text { Pillars of Sus- } \\
\text { tainability }\end{array}$ & Legal requirements \\
\hline Social pillar & $\begin{array}{l}\text { Greater job creation and use of local labor. (Normative Instruction n. 01/2010; De- } \\
\text { cree n. 7.746/2012). } \\
\text { Maior geração de empregos e uso de mão de obra local (IN 01/2010; Decreto } \\
7.746 / 2012) \text {. }\end{array}$ \\
\hline $\begin{array}{l}\text { Environmental } \\
\text { pillar }\end{array}$ & $\begin{array}{l}\text { Stimulus and promotion of sustainable patterns of production and consumption, adop- } \\
\text { tion of preference criteria in biddings to proposals that generate higher economy of } \\
\text { natural resources and reduction of greenhouse gases and waste (Law n. 12.187/2009). } \\
\text { Priority in the governmental acquisitions and hires to recycled and recycling produc- } \\
\text { ts which consider criteria compatible to patterns of social consumption and environ- } \\
\text { mentally sustainable (Law n. 12.305/2010). } \\
\text { Energetic efficiency, reduction of the water consumption, use of renewable energy, } \\
\text { management of waste, biodegradability and traceability (NI n. 01/2010). } \\
\text { Lower impact and higher efficiency on the use of natural resources (Decree n. } \\
\text { 7.746/2012). }\end{array}$ \\
\hline Economic pillar & $\begin{array}{l}\text { Promotion of the national sustainable development. Authorization of preference mar- } \\
\text { gin to manufactured products and national services that meet the Brazilian technical } \\
\text { rules (Law n. 12.349/2010). } \\
\text { Preference to local materials, technologies and raw materials; longer lifetime and lower } \\
\text { maintenance cost of the good and the work (Decree n. 7.746/2012; NI n. 01/2010). }\end{array}$ \\
\hline
\end{tabular}

Source: the authors.

The three pillars of sustainability are contemplated by the legislation. The social, through job creation, the stimulus to the development and growth of the small business and still the ones related to the human and the labor rights. The most evident factors related to the economic pillar are on the cost reduction, even in long-term, and in the regional and national development. The aspects referring to the environmental pillar are identified in the actions that involve reduction of the consumption and of the use of natural resources, proper disposal for waste, as well as the foment to the recycling practice and the reduction of gas emission. The legislation widely contemplates the economic and environmental pillars of sustainability, but there are no clear actions related to the social pillar. However, it shall be considered the fact that meeting one 
pillar makes it possible to, indirectly, meet another one, necessary, still, to observe the intersections between the pillars, according to what was previously exposed.

\subsection{BIDDING PROCESSES IN THE IMPLANTATION OF THE UNIVERSITY RESTAURANT OF UFFS}

On Board 5, it was sought to list the processes held to the implantation of the University Restaurant of Universidade Federal da Fronteira Sul, in which the numbers of the processes and their description are presented, and the sustainability criteria are identified.

Board 5 - Bidding processes and sustainability criteria identified

\begin{tabular}{|c|c|c|}
\hline N. of the process & Description & Sustainability criteria \\
\hline $23205.000736 / 2010-67$ & $\begin{array}{l}\text { Hiring company to develop project } \\
\text { of the UR. }\end{array}$ & $\begin{array}{l}\text { Well-dimensioned/equated projects, as } \\
\text { to conventional solutions as to environ- } \\
\text { mentally correct ones. } \\
\text { Study of technical and economic viabili- }\end{array}$ \\
\hline 23205.007054/2011-10 & $\begin{array}{l}\text { Competition n. 09/2011 } \\
\text { UR - Cerro Largo }\end{array}$ & $\begin{array}{l}\text { ty of the use of self-sustainable systems } \\
\text { of water reuse and solar heating system. } \\
\text { Accessibility. } \\
\text { Solar heating system. }\end{array}$ \\
\hline 23205.007056/2011-17 & $\begin{array}{l}\text { Competition n. 10/2011 } \\
\text { UR - Chapecó }\end{array}$ & $\begin{array}{l}\text { Water reuse. } \\
\text { Reduction of the electric power and gas } \\
\text { consumption. }\end{array}$ \\
\hline 23205.007057/2011-53 & $\begin{array}{l}\text { Competition n. 12/2011 } \\
\text { UR - Erechim }\end{array}$ & $\begin{array}{l}\text { Use of less pollutant, with quality and } \\
\text { extensive warrantees materials. } \\
\text { Exigence of certification ISO } 9001 \text { and } \\
\text { ISO } 14001 \text {. }\end{array}$ \\
\hline 23205.007058/2011-06 & $\begin{array}{l}\text { Competition n. 11/2011 } \\
\text { UR - Laranjeiras do Sul }\end{array}$ & $\begin{array}{l}\text { Appropriate sewage treatment. } \\
\text { Work conditions. } \\
\text { Economic/financial capability of the }\end{array}$ \\
\hline 23205.007059/2011-42 & $\begin{array}{l}\text { Competition n. 08/2011 } \\
\text { UR - Realeza }\end{array}$ & $\begin{array}{l}\text { contractor. } \\
\text { Preference margin. } \\
\text { Automatic faucets. } \\
\text { Solar orientation. }\end{array}$ \\
\hline 23205.001096/2013-17 & $\begin{array}{l}\text { Eletronic auction n. 47/2013 } \\
\text { Equipment UR }\end{array}$ & $\begin{array}{l}\text { Certificate of the wood origin. } \\
\text { Certificate of the energy consumption. } \\
\text { Preference margin. }\end{array}$ \\
\hline
\end{tabular}




\begin{tabular}{|c|c|c|}
\hline 23205.000485/2014-06 & $\begin{array}{l}\text { Eletronic auction n. 18/2014 } \\
\text { Food acquisition - UR Chapecó }\end{array}$ & \multirow{4}{*}{$\begin{array}{l}\text { Attendance of appropriate hygienic and } \\
\text { sanitary conditions (expiration, quality } \\
\text { and food transportation). } \\
\text { Preference margin. }\end{array}$} \\
\hline 23205.000495/2014-33 & $\begin{array}{l}\text { Eletronic auction n. 19/2014 } \\
\text { Food acquisition - UR Realeza }\end{array}$ & \\
\hline 23205.000618/2014-36 & $\begin{array}{l}\text { Eletronic auction n. 21/2014 Food } \\
\text { acquisition - UR Erechim }\end{array}$ & \\
\hline 23205.000692/2014-52 & $\begin{array}{l}\text { Eletronic auction n. 23/2014 Food } \\
\text { acquisition - UR Cerro Largo }\end{array}$ & \\
\hline
\end{tabular}

Source: the authors.

The competition proceedings held to the hiring of company to the work execution of the Universitary Restaurants of Universidade Federal da Fronteira Sul were analyzed; they cover the material and labor supply. The proceedings related to the hiring of the company which designed the project were also object of the analysis, as well as the auctions related to the equipment and food acquisition. It was observed that economic, social and environmental sustainability criteria are included in the relevant documents.

The criteria that can be associated to the social pillar involve accessibility, with ticket gates, toilets and access benches to people with special needs and tactile paving. Declaration related to not having minors in unhealthy, dangerous and/or night works, considering the ages determined in law to each situation, compliance with medicine and labor safety rules. Stimulus and benefits to the small and micro business.

In the environmental scope, it was possible to cover aspects regarding the use of solar energy, reuse of rainwater, high efficiency illumination, aiming the reduction of Liquefied petroleum gas and electricity consumption, acquisition of air-conditionings with "A" classification according to the program PROCEL-INMETRO. Still, the compliance with the quality of materials, durability and choice of less polluting materials were identified. Criteria referring to the appropriate sewage treatment were also found.

In relation to the economic pillar, the aspects regularity of businesses related to the taxes and regulatory bodies and the financial capability to the work execution were observed. Indexes of General Liquidity, General Solvency and Current Liquidity were defined, and, in some cases, minimum net worth evidence of $10 \%$ of the contract value, as well as the requirement of guarantee from the contractor. It is also observed the respect to the preference margin to micro and small businesses, as referred in the specific legislation. The preference margins meet both the economic pillar and the social ones, because the development of these businesses may mean job creation and improvement of the population's quality of life.

It was also observed the solicitation for the manufacturer to have ISO $9001 \mathrm{e}$ ISO 14001 certification, compliance with the law that regulates the biddings and the 
sustainable biddings and with the several specific normatizations of each area. To the food procurement to the URs, some hygienic and sanitary criteria were included, which involve: food packaging in nontoxic recipients, transportation and controlled load temperature, and sanitary permit of suppliers and transport companies. Compliance to the Resoluções da Diretoria Colegiada (RDC) [Collegiate Directorate Resolution] from National Health Surveillance Agency (Anvisa), regarding these foods.

\subsection{PERCEPTION OF THOSE RESPONSIBLE FOR THE AREA IN THE RESEARCHED INSTITUTION REGARDING THE SUSTAINABLE PROCUREMENT}

Board 6 shows the respondents' perception about the sustainable biddings, considering the economic, social and environmental dimensions.

Board 6 - Respondents' perception about the sustainable procurements

\begin{tabular}{|c|c|}
\hline Dimension & Perceptions \\
\hline Economic & $\begin{array}{l}\text { E3 “The government, when it created this sustainable issue [...] was wondering about } \\
\text { the national sustainable development, also in an economic point of view." } \\
\text { E1 “[...] the sustainable procurements enable long-term economy." } \\
\text { E2 “[...] one of the functions of the bidding is to promote the national sustainable } \\
\text { development. } \\
\text { E3 “[...] most used criteria [...] matter of preference margin to national products.” } \\
\text { E3 “[...] benefits that the government gives to the micro and small businesses." } \\
\text { E3 “[...] foment to the development of national products, incentive to the research and } \\
\text { development of new products. } \\
\text { E4 "International rules of production process certification are very hard to access for } \\
\text { the small business, it hampers sustainability.” (our translation). }\end{array}$ \\
\hline Environmental & 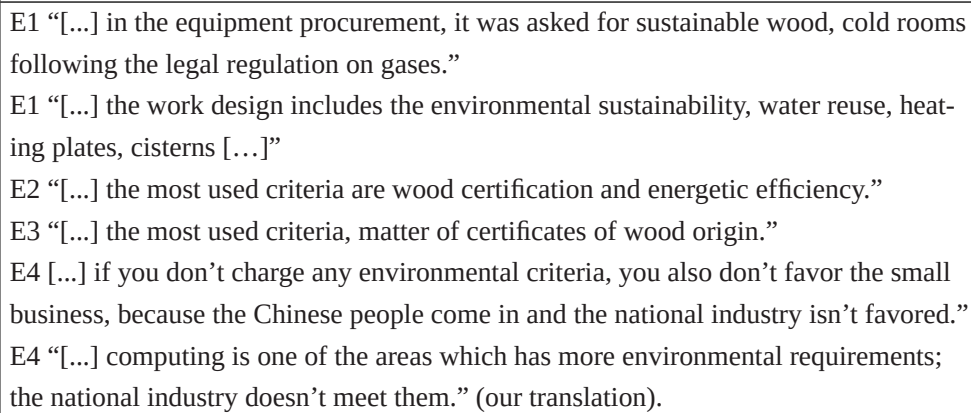 \\
\hline
\end{tabular}




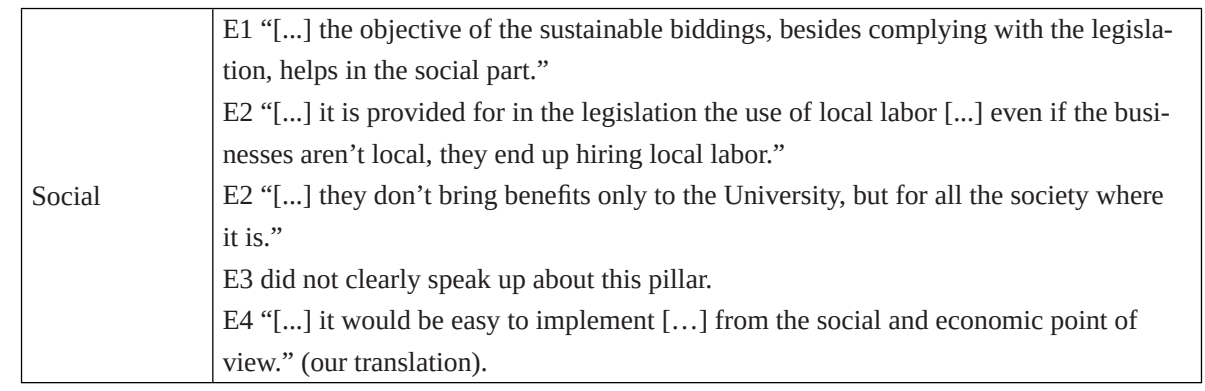

Source: the authors.

The research subjects demonstrate to have a wide perception of sustainability, covering the three pillars. However, it was possible to identify that the participants' individual perception is very influenced by their formation. Even developing similar professional activities, it was possible to see a significant difference on the emphasis in each pillar, economic, environmental and social. The participant with Administration formation showed greater knowledge about the economic pillar, the one with Biology formation masters the environmental pillar, and the one with Nutrition formation presented integrate and generic knowledge about the three pillars.

The potentialities and weaknesses of the bidding process of sustainable nature within UFSS were presented, more specifically, related to the implantation of the University Restaurant, thus, proposals to adequacies arose, aiming improvements.

\subsection{PROPOSITION OF ADAPTATIONS AND IMPROVEMENTS TO THE BIDDING PROCESS OF SUSTAINABLE NATURE}

Among the proposed actions to the improvement of the bidding process of sustainable nature, the ones related to the awareness are highlighted. According to E2, it is very important to strengthen the virtual campaigns, which aim the awareness of the academic community that may go on to their families. The preference to disclose through digital media was due to the printed media may mean more consumption, which affects both the economic and environmental pillars.

The training and the qualification of everyone involved in the process, including the servants directly linked to the sustainable procurements, the procurement applicants and agents and, still, the suppliers, may contribute substantially to the implementation and strengthening of sustainable biddings. E4 points out that some problems are "[...] related to the lack of planning and to the unawareness of the institution's rules.” (verbal information, our translation). According to E1, “[...] 
the applicant's qualification is necessary, more information on the legislation, on the proposals of the law and on the impacts that it can generate." (verbal information, our translation). In accordance with this idea, E2 stresses that one of the difficulties is the lack of consistent literature on the area; everything that reports sustainable bidding is very new. The procurement agents do not insert sustainability criteria because they still cannot preview what they can order related to sustainability. In relation to the suppliers, E3 raises the issue of the unawareness on the recent legislation.

Another very important action is the creation of a sustainable core, which could develop with the campuses the implementation of actions regarding sustainability, as well as the monitoring of the results through indicators. This core could act on the targets planning and definition. According to Alencastro, Silva and Lopes (2014), the targets should be stablished clearly; the body may, for example, determine a percentage of sustainable or hiring products which include the sustainable criteria. E2 stresses that the creation of the core could institutionalize actions that, currently, are developed separately by certain sectors or campuses of the University.

According to E4, “[...] there should be policies involving the specific bodies to foment sustainability” and this responsibility should not be assigned to the bidding. This respondent mentions that the "[...] inspection of some specific rules as of the work legislation, correct material waste, should be done by the bodies responsible for these areas and not by the institution that holds the bidding." (verbal information, our translation). He also suggested the creation of "national certifications" with the appropriate inspection, and the conference is up to the bidder institution. Whomever has this certificate or stamp would be able to compete, otherwise, would not. In other words, according to A4, the inspection of the requirements of sustainability should be assigned to the competent bodies and not to the institutions that make their procurements within the current legislation.

Even presenting some fragilities, mainly resulting from the fact that sustainability practices regulated by rules and laws are recent in the public institutions and by the greater emphasis on the environmental aspects, the model used in Universidade Federal da Fronteira Sul, in general, is very good. The Institution should foment the practice and seek to meet all the pillars of sustainability, even if it needs to include additional criteria in its bidding processes, a fact provided for in the legislation, since it does not harm the bidding competitiveness. In E4's view, “[...] the work in UR is a model of sustainability and meets all sustainability rules.” (verbal information, our translation).

Board 7 shows a comparative synthesis between the pillars of sustainability related to the legislation, to the authors' and participants' opinion and to the criteria adopted in the bidding processes to the implantation of the University Restaurant of UFFS. 
Board 7 - Comparative synthesis

\begin{tabular}{|c|c|c|c|c|}
\hline $\begin{array}{l}\text { Sustainable } \\
\text { pillars }\end{array}$ & Pertinent legislation & Authors' opinion & $\begin{array}{l}\text { Participants' opin- } \\
\text { ion }\end{array}$ & $\begin{array}{l}\text { Bidding processes } \\
\text { of the UR - UFFS }\end{array}$ \\
\hline Economic & $\begin{array}{l}\text { Law n. } 12.349 / 2010 \\
\text { and NI n. 01/2010: } \\
\text { preference for } \\
\text { national products, } \\
\text { technology and } \\
\text { services, within the } \\
\text { specifications, with } \\
\text { longer life and lower } \\
\text { maintenance cost. }\end{array}$ & $\begin{array}{l}\text { Oliveira et al. (2012): } \\
\text { it aims to create } \\
\text { viable enterprises. } \\
\text { Elkington (2001): } \\
\text { thinking beyond } \\
\text { profit, considering } \\
\text { the sustainability } \\
\text { of the demand, } \\
\text { in relation to the } \\
\text { prices, profit margin } \\
\text { and innovation. }\end{array}$ & $\begin{array}{l}\text { Focus on the na- } \\
\text { tional sustainable } \\
\text { development, with } \\
\text { preference for } \\
\text { national products } \\
\text { and stimulus to } \\
\text { micro and small } \\
\text { businesses. }\end{array}$ & $\begin{array}{l}\text { Study of viability } \\
\text { that assures good } \\
\text { use of public re- } \\
\text { source. Study of } \\
\text { the economic and } \\
\text { financing capability } \\
\text { of the contractors. }\end{array}$ \\
\hline Environmental & $\begin{array}{l}\text { Law n. } \\
\text { 12.187/2009, Law } \\
\text { n. 12.305/2010, De- } \\
\text { cree n. 7.746/2012: } \\
\text { stimulus to the } \\
\text { economy of natural } \\
\text { resources with pref- } \\
\text { erence for recycled } \\
\text { or recycling prod- } \\
\text { ucts, with energetic } \\
\text { efficiency, reduction } \\
\text { ow water consump- } \\
\text { tion, etc. }\end{array}$ & $\begin{array}{l}\text { Elkington (2001): } \\
\text { it is related to the } \\
\text { preservation of the } \\
\text { Planet. } \\
\text { Araújo et al. (2006): } \\
\text { it covers all the } \\
\text { clean Technologies, } \\
\text { recycling, environ- } \\
\text { mental impacts and } \\
\text { others. }\end{array}$ & $\begin{array}{l}\text { Stimulus to the } \\
\text { use of sustainable } \\
\text { wood, equipment } \\
\text { within the lower } \\
\text { energy consumption } \\
\text { specifications and } \\
\text { reduction of gases, } \\
\text { constructions with } \\
\text { water reuse, use of } \\
\text { solar energy, etc. }\end{array}$ & $\begin{array}{l}\text { Requirements of } \\
\text { certificates of the } \\
\text { wood origin and en- } \\
\text { ergy consumption. } \\
\text { Use of self-sus- } \\
\text { tained systems of } \\
\text { water and solar } \\
\text { energy reuse. } \\
\text { Use of less pollut- } \\
\text { ant materials. } \\
\text { Requirement of } \\
\text { certification } \\
\text { ISO } 9001 \text { and } \\
\text { 14001. } \\
\text { Requirement of hy- } \\
\text { gienic and sanitary } \\
\text { conditions in the } \\
\text { food procurement. }\end{array}$ \\
\hline Social & $\begin{array}{l}\text { Decree } n \text {. } \\
7.746 / 2012 \text { and NI } \\
01 / 2010 \text { : stimulus } \\
\text { to job creation and } \\
\text { use of local labor. }\end{array}$ & $\begin{array}{l}\text { Araújo et al. (2006): } \\
\text { it is focused on the } \\
\text { social responsibility, } \\
\text { on the support to the } \\
\text { community growth } \\
\text { and on the promo- } \\
\text { tion and participation } \\
\text { in social projects. }\end{array}$ & $\begin{array}{l}\text { It seeks to pro- } \\
\text { duce benefits to } \\
\text { the whole society. } \\
\text { Stimulus to the use } \\
\text { of local labor. }\end{array}$ & $\begin{array}{l}\text { Attention to the } \\
\text { accessibility and } \\
\text { to the work condi- } \\
\text { tions. }\end{array}$ \\
\hline
\end{tabular}

Source: the authors. 
Board 7 allows, in first place, to show that the general and specific objectives of this study have been achieved. Secondly, it reinforces results of other researches which indicate greater compliance of the economic and environmental pillars, rather than the social pillar, which got slight attention both from the participants and from the criteria observed in the bidding processes of UR - UFFS. In this terms and in third place, the improvement proposals of investing in the awareness of the academic community to the sustainable issues and commitments and to the creation of the Centre of Sustainability of institutional nature to reflect and plan the advances, in special in the Social Pillar, take shape.

\section{FINAL CONSIDERATIONS}

The aim with this study was to verify if the hiring done to the implantation of the UR of UFFS meet the three sustainable pillars. In order to obtain the results, specific objectives were defined. Aiming to achieve these objectives, a bibliographic research, a documental research and interviews were elaborated. The information collected through data collection were organized in order to respond to the objectives proposed.

It was found that sustainability criteria were included in the bidding processes performed until now to the implantation of the University Restaurant of Universidade Federal da Fronteira Sul.

It was not verified balance between the three sustainable pillars, since the actions focused to the environmental and economic sustainability were more evident, confirming what has been presented in theory and in related studies. This fact was found also in the interviews related to the perception of the servants involved in the procurement process of the Institution. Considering these aspects, it is concluded that to the compliance of the three pillars of sustainability, the Institution needs to pay attention to the social issue as well. Another relevant factor was the fact that the respondents' perception about sustainability emphasized certain pillar according to their formation.

Among the main contributions of this study, it is possible to stress the finding of the greater difficulties found to the implementation of sustainable procurements, among them, the ones related to the awareness of the academic community and of the procurement agents in relation to sustainability. Another relevant factor observed was referring to the information, both of the suppliers and of the servants involved in the process, regarding the knowledge about the legislation and the impact that actions focused in sustainability can bring to the institution and to the whole society. 
One action proposed by the participants is the creation of a centre of sustainability of institutional nature and intercampus to disseminate information and foment the expansion of the compliance of the sustainable pillars, in special, the social one.

As a restriction of the study, it is cited the difficulty of analysis of the processes referring to the work of the University Restaurant, for it involves a huge range of technic terms which hamper the process of analysis.

In terms of recommendations to future studies, one possibility would be the analysis of the next processes involving the University Restaurant, for example, the hiring of third-party company to the supply of meals or the next procurement processes which will possibly involve the direct procurement of the familiar agriculture and acquisition of organic food.

\section{REFERENCES}

ALENCASTRO, M. A. C.; SILVA, E. V.; LOPES, A. M. D. Contratações sustentáveis na administração pública brasileira: a experiência do Poder Executivo federal. Revista Administração Pública, Rio de Janeiro, v. 48, n. 1, p. 207-235, jan./fev. 2014. Available from: <http://www.scielo.br/scielo.php?pid=S0034-7612201400010 0009\&script=sci_arttext>. Access on: Mar. 182016.

ARAÚJO, G. C. et al. Sustentabilidade Empresarial: conceitos e indicadores. In: CONGRESSO VIRTUAL BRASILEIRO DE ADMINISTRAÇÃO, 3., 2006. Available from: <http://www.convibra.com.br/2006/artigos/61_pdf.pdf>. Access on: Mar. 182016.

BARDIN, L. Análise de conteúdo. São Paulo: Edições 70, 2011.

BELL, J. Projeto de pesquisa: guia para pesquisadores iniciantes em educação, saúde e ciências sociais. 4. ed. Porto Alegre: Artmed, 2008.

BIDERMAN, R. et al. Guia de Compras Públicas Sustentáveis: Fundação Getúlio Vargas e ICLEI. 2. ed. Rio de Janeiro: Editora FGV, 2008. Available from: <http:// www.gvces.com.br/arquivos/36/Guia-de-compras-publicas-sustentaveis.pdf $>$. Access on: Mar. 182016.

BINSWANGER, H. C. Fazendo a sustentabilidade funcionar. In: CAVALCANTI, C. Meio ambiente, desenvolvimento sustentável e políticas públicas. 4. ed. São Paulo: Cortez, 2002. 
BRASIL. Cartilha A3P: Agenda ambiental da administração pública. Brasília: MMA; SDS; PNEA, 2009a.

BRASIL. Constituição. República Federativa do Brasil de 1988. Brasília, DF: Senado Federal: 1988. Available from: <http://www.planalto.gov.br/ccivil_03/constituicao/constituicaocompilado.htm>. Access on: Mar. 182016.

BRASIL. Decreto n. 7.404, de 23 de dezembro de 2010. Regulamenta a Lei n. 12.305, de 02 de agosto de 2010, que institui a Política Nacional de Resíduos Sólidos, cria o Comitê Interministerial da Política Nacional de Resíduos Sólidos e o Comitê Orientador para a Implantação dos Sistemas de Logística Reversa, e dá outras providências. Diário Oficial da União, 23 dez. 2010a. Available from: <http:// www.planalto.gov.br/ccivil_03/_ato2007-2010/2010/Decreto/D7404.htm>. Access on: Mar. 182016.

BRASIL. Decreto n. 7.746, de 05 de junho de 2012. Regulamenta o art. $3^{\circ}$ da Lei $n^{\circ}$ 8.666, de 21 de junho de 1993, para estabelecer critérios, práticas e diretrizes para a promoção do desenvolvimento nacional sustentável nas contratações realizadas pela administração pública federal, e institui a Comissão Interministerial de Sustentabilidade na Administração Pública - CISAP. Diário Oficial da União, 05 jun. 2012a. Available from: <http://www.planalto.gov.br/ccivil_03/_Ato2011-2014/2012/Decreto/D7746.htm>. Access on: Mar. 182016.

BRASIL. Instrução Normativa n. 01, de 19 de janeiro de 2010. Dispõe sobre os critérios de sustentabilidade ambiental na aquisição de bens, contratação de serviços ou obras pela Administração Pública Federal direta, autárquica e fundacional e dá outras providências. 2010b. Available from: <http://www.comprasnet.gov.br/legislacao/legislacaoDetalhe.asp?ctdCod=295> . Access on: Mar. 182016.

BRASIL. Instrução Normativa n. 10, de 12 de novembro de 2012. Estabelece regras para elaboração dos Planos de Gestão de Logística Sustentável de que trata o art. 16, do Decreto ${ }^{0}$ 7.746, de 5 de junho de 2012, e dá outras providências. Diário Oficial da União, 14 nov. 2012b. Available from: <http://cpsustentaveis.planejamento.gov. br/wp-content/uploads/2012/11/Instru\%C3\%A7\%C3\%A3o-Normativa-10-2012. pdf>. Access on: Mar. 182016.

BRASIL. Lei n. 8.666, de 21 de junho de 1993. Regulamenta o art. 37, inciso XXI, da Constituição Federal, institui normas para licitações e contratos da Administração Pública e dá outras providências. Diário Oficial da União, Brasília, DF, 22 jun. 1993. Available from: <http://www.planalto.gov.br/ccivil_03/Leis/L8666cons.htm>. Access on: Mar. 182016. 
BRASIL. Lei n. 10.257, de 10 de julho de 2001. Regulamenta os arts. 182 e 183 da Constituição Federal, estabelece diretrizes gerais da política urbana e dá outras providências. Diário Oficial da União, Brasília, DF, 11 jul. 2001. Available from: $<$ http://www.planalto.gov.br/ccivil_03/leis/leis_2001/110257.htm> Access on: Mar. 182016.

BRASIL. Lei n. 12.187, de 29 de dezembro de 2009. Institui a Política Nacional sobre Mudança do Clima - PNMC e dá outras providências. Diário Oficial da União, Brasília, DF, 30 dez. 2009. Available from: <http://www.planalto.gov.br/ccivil_03/_ ato2007-2010/2009/lei/l12187.htm>. Access on: Mar. 182016.

BRASIL. Lei 12.305 de 02 de agosto de 2010. Institui a Política Nacional de Resíduos Sólidos; altera a Lei no 9.605, de 12 de fevereiro de 1998; e dá outras providências. Diário Oficial da União, Brasília, DF, 03 ago. 2010c. Available from: <http://www.planalto.gov.br/ccivil_03/_ato2007-2010/2010/lei/112305.htm> Access on: Mar. 182016.

BRASIL. Lei n. 12.349 de 15 de dezembro de 2010. Altera as Leis nos 8.666, de 21 de junho de 1993, 8.958, de 20 de dezembro de 1994, e 10.973, de 2 de dezembro de 2004; e revoga o § 1o do art. 2o da Lei no 11.273, de 6 de fevereiro de 2006.

Diário Oficial da União, Brasília, DF, 15 dez. 2010d. Available from: <http://www. planalto.gov.br/ccivil_03/_Ato2007-2010/2010/Lei/L12349.htm>. Access on: Mar. 182016.

CASTRO, D. P. Auditoria e controle interno na administração pública: evolução do controle interno no Brasil: do Código de Contabilidade de 1922 até a criação da CGU em 2003: guia para atuação das auditorias e organização dos controles internos nos Estados, municípios e ONGs. 2. ed. São Paulo: Atlas, 2009.

CASTRO, R. G.; LIMA, D. V. Contabilidade pública: integrando União, Estados e Munícipios (Siafi e Siafem). 3. ed. São Paulo: Atlas, 2011.

COLLIS, J.; HUSSEY, R. Pesquisa em administração: um guia prático para alunos de graduação e pós-graduação. 2. ed. Porto Alegre: Bookman, 2005.

COMISSÃO MUNDIAL SOBRE MEIO AMBIENTE E DESENVOLVIMENTO. Nosso futuro comum. 2. ed. Rio de Janeiro: FGV, 1991.

CRESWELL, J. W. Projeto de Pesquisa: métodos qualitativos, quantitativos e misto. 3. ed. Porto Alegre: Artmed, 2010. 
ELKIGNTON, J. A Teoria dos Três Pilares. In: ELKIGNTON, J. Canibais com garfo e faca. São Paulo: Makron Books, 2001.

GODOY, A. S. Pesquisa qualitativa: tipos fundamentais. Revista Administração de Empresas, São Paulo, v. 35, n. 3, p. 20-29, jun. 1995. Available from: <http:// www.scielo.br/scielo.php?script=sci_arttext\&pid=S0034-75901995000300004\&lng=en\&nrm=iso>. Access on: Mar. 182016.

JUSTEN FILHO, M. Pregão: comentário à legislação do pregão comum e eletrônico. 5. ed. rev. e atual. de acordo com a Lei Federal n. 10520/2002 e os Decretos Federais n. 3.555/00 e 5.450/05. São Paulo: Dialética, 2009.

MELO, P. T. N. B. Indicadores da Dimensão Institucional do Desenvolvimento Sustentável e os Objetivos da Rio +20. Desenvolvimento em Questão, v. 11, n. 23, p. 74-117, maio/ago. 2013. Available from: <https://www.revistas.unijui.edu.br/index. php/desenvolvimentoemquestao/article/view/308/1319>. Access in: Mar. 182016.

OLIVEIRA, L. R. et al. Sustentabilidade: da evolução dos conceitos à implementação como estratégia nas organizações. Produção, v. 22, n. 1, p. 70-82, jan./fev. 2012.

SACHS, I.; LOPES, C.; DOWBOR, L. Crises e oportunidades em tempos de mudança. Documento de referência para as atividades do núcleo Crises e Oportunidades no Fórum Social Mundial Temático. Bahia, 2010.

SEN, A. Desenvolvimento como liberdade. São Paulo: Companhia das Letras, 2010.

UNIVERSIDADE FEDERAL DA FRONTEIRA SUL - UFFS. Perfil. Disponível em: <http://www.uffs.edu.br/index.php?option=com_content\&view=article\&id=370\&Itemid=823> . Access on: Mar. 182016.

VAN BELLEN, H. M. Indicadores de sustentabilidade: um levantamento dos principais sistemas de avaliação. Cadernos EBAPE.BR, v. 2, n. 1, p. 1-14, mar. 2004. Available from: <http://www.scielo.br/scielo.php?pid=S1679-39512004000100002 \&script=sci_arttext> Access on: Mar. 182016.

YIN, R. K. Estudo de Caso: planejamento e métodos. 4. ed. Porto Alegre: Bookman, 2010. 
How to mention this paper:

\section{ABNT:}

WEBER, Josiane; MACHADO, Nelson Santos. Sustainable public biddings: the case of Universidade Federal da Fronteira Sul's university restaurant. RACE, Revista de Administração, Contabilidade e Economia, Joaçaba: Ed. Unoesc, v. 15, n. 2, p. 419-446, maio/ago. 2016. Available from: < http://editora.unoesc.edu.br/index. php/race>. Access on: month/day/year.

\section{APA:}

Weber, J., \& Machado, N. S. (2016). Sustainable public biddings: the case of Universidade Federal da Fronteira Sul's university restaurant. RACE, Revista de Administração, Contabilidade e Economia, 15(2), 419-446. Retrieved from http://editora. unoesc.edu.br/index.php/race 